\title{
The measurement of local blood flow in the cerebral cortex from the clearance of xenon ${ }^{133}$
}

\author{
A. M. HARPER, H. I. GLASS, J. L. STEVEN, AND A. H. GRANAT \\ From the St. Mungo Department of Surgery, Glasgow Royal Infirmary, the Wellcome Research Laboratories, \\ University of Glasgow, the Regional Physics Department, Western Regional Hospital Board, and the Western \\ Regional Neurosurgical Unit, Killearn Hospital, Glasgow
}

Recently Lassen and Ingvar (1961) devised a technique for measuring local blood flow through the cerebral cortex. Their method, derived from the Fick principle, entailed the injection of the radioactive gas krypton ${ }^{85}$ into the carotid artery and the subsequent measurement of the rate of clearance from the brain of the beta emissions of the isotope. As these have an average range in tissue of $0.7 \mathrm{~mm}$., measurements of local blood flow can be made only on the exposed brain cortex. A more recent report describes the measurement of regional cerebral blood flow in man by monitoring the low incidence gamma emissions of krypton ${ }^{85}$ with a scintillation detector placed over the scalp (Lassen, HøedtRasmussen, Sørensen, Skinhøj, Cronquist, Bodforss, and Ingvar, 1963). However, in that study uncollimated detectors were used in most patients, and the clearance of krypton ${ }^{85}$ was recorded from almost one hemisphere of the brain.

Recently we reported the substitution of the gamma-emitting isotope xenon ${ }^{133}$ for $\mathrm{Kr}^{85}$ and the measurement of local blood flow in a fairly small area of the cerebral cortex by external counting through the intact skull using a depth-focusing collimator (Glass and Harper, 1963). This paper describes measurements made in several patients who were undergoing cerebral angiography.

\section{METHOD}

Xenon ${ }^{133}$ was received in 100 mc. doses in a sealed glass ampoule, which was connected to a glass reservoir which had been previously evacuated with a vacuum pump. On breaking the seal the gas entered the reservoir and the remaining space was filled with normal saline. Aliquots of the solution, each of $20 \mathrm{ml}$., were withdrawn into syringes. Each syringe contained approximately $0 \cdot 5-$ $1 \mathrm{mc}$. of radioactivity.

Measurements of cortical blood flow were made on anaesthetized patients undergoing cerebral angiography for suspected intracranial lesions. Anaesthesia was induced with thiopentone and maintained with $75 \%$ $\mathrm{N}_{2} \mathrm{O}$ and oxygen. D-tubocurarine $(15-25 \mathrm{mg}$.) was ad- ministered and additional doses of $10 \mathrm{mg}$. were given as required. The patients were ventilated with intermittent positive pressure on a Barnett ventilator. An open circuit was used and the expired gases led to the outside atmosphere through a thick-walled plastic tube.

The detector consisted of a focusing collimator, a 5-in. diameter sodium iodide crystal, and a photomultiplier. The last was connected to a ratemeter and direct writing recorder. The focusing collimator was mounted in front of the crystal and localized the area of cortex under view. The collimator was lowered by a special stand on to the patient's scalp, when the centre of the collimator lay above the posterior part of the frontal cortex.

A catheter was inserted into the internal carotid artery via the common carotid artery. The position of the catheter was confirmed by radiography.

About $10-15 \mathrm{ml}$. of the saline solution of $x^{13}{ }^{133}$ was injected, rapidly at first, then more slowly into the cannula over two and a half minutes. On completion of the injection, a clearance curve was obtained on the recorder. This was transposed on to semilogarithmic paper and the flow calculated from the half-life of the initial slope of the clearance curve, using the formula, flow (ml./g./min.) $=$ $\frac{\lambda \log _{\mathrm{e}} 2 \times 60}{\mathrm{~T}_{\frac{1}{2}}}$ (Ingvar and Lassen, 1962), where $\mathrm{T}_{\frac{1}{2}}=$ half life in seconds of the initial slope of the clearance curve and $\lambda=$ brain-blood partition coefficient for xenon ${ }^{133}$. The value used for the latter was $\mathbf{0} \cdot 80$ (Mallet and Veall, 1963). A sample of carotid artery blood was taken after each flow estimation for the measurement of the arterial carbon dioxide tension on the micro-Astrup apparatus (Siggaard Andersen, Engel, Jørgensen, and Astrup, 1960).

\section{THEORY OF INERT GAS CLEARANCE METHOD}

The rationale of inert gas clearance methods is illustrated in Figure 1. Following its injection into the carotid artery, xenon diffuses in a known ratio between the blood and brain tissue. After a sufficiently long injection period the brain tissue and venous blood will be in equilibrium. On cessation of the injection the carotid arterial blood, now containing virtually no radioactive xenon, will wash out the xenon in the brain tissue and the rate at which this 

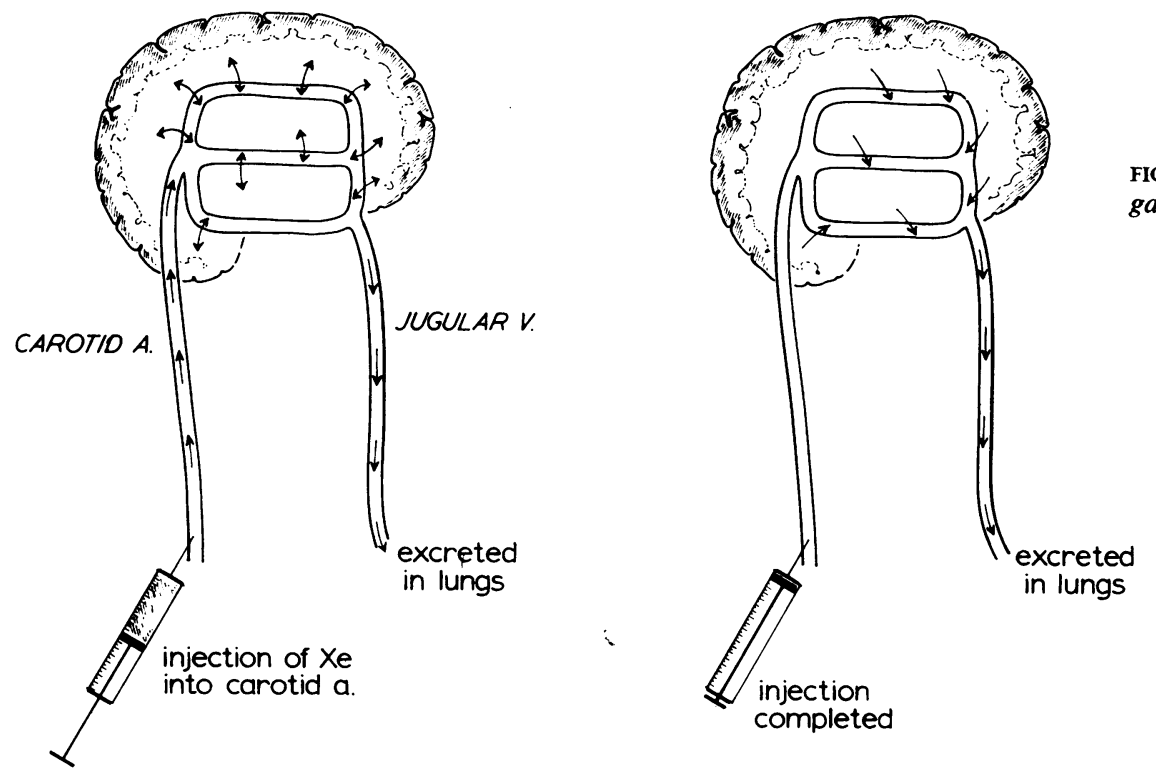

FIG. 1. Rationale of inert gas clearance method.

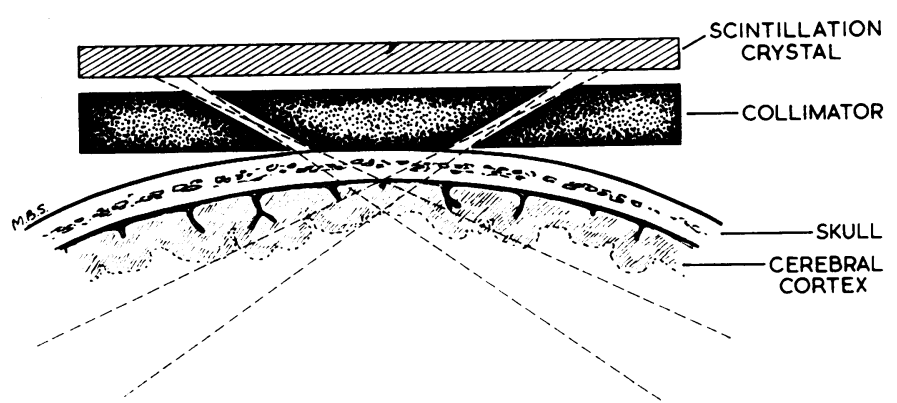

FIG. 2. Diagram of simple collimat 娄

takes place will depend on the quantity of blood perfusing the brain. As the air:blood partition coefficient for xenon is $10: 1$, the gas is almost completely cleared in the lungs and the effect of the small amount of arterial recirculation on the initial slope of the clearance curve can be calculated. It must be emphasized that the entry of xenon into the brain tissue and its subsequent clearance is a purely physical process, and depends only on diffusion and solubility.

As the cerebral cortex is not a completely homogenous tissue and has a multi-exponential clearance curve, the injection time must be long enough to ensure equal concentrations of the inert gas in all the cortical tissue components. We have found that an initially rapid, then slow, injection of approximately two and a half minutes will achieve this.

\section{DETECTION OF RADIOACTIVITY}

The level of radioactivity in an area of the cerebral cortex is detected by means of a depth-focusing collimator placed in front of a scintillation crystal. A cross-section of a very simple collimator is shown diagrammatically in Figure 2. It consists of a lead $\frac{\mathrm{O}}{\Phi}$ disc $\frac{1}{2}$ in. thick in which a circular tapered channel $\frac{\varrho}{2}$ has been cut. Radioactive emissions can reach the $\overrightarrow{0}$ crystal only through this channel. The maximum 3 efficiency of counting comes from the area of cortex completely enclosed by the dotted lines. Outside the radiating lines some radioactivity will be recorded on a more limited area of the crystal but its effect willo be reduced by distance, by absorption in tissue, ando by the fact that white matter, with its much slower blood flow, contains less radioactivity.

With the more complex twin-channel multiseg- 3 mented collimators which we now use for ouro measurements in man (Glass, 1963), the initial slope of the clearance curve is due to clearance of xenon from a volume of brain tissue approximately $4 \mathrm{~cm}$. N in diameter by up to $2 \mathrm{~cm}$. in depth, the latter being . controlled by adjusting the position of the collimator ${ }^{N}$ relative to the skin. 
RADIATION HAZARD

Xenon $^{133}$ has a biological half-life of only a few minutes and is cleared very rapidly from the lungs. The radiation dose to the lungs for a two-minute rebreathing of a concentration of xenon of $1 \mathrm{mc}$./litre of inspired air is 70 millirads (Dollery, Hugh-Jones, and Matthews, 1962; Matthews, Fowler, and Turner, 1962) and the dose following an intravascular injection of $0.5 \mathrm{mc}$. is much smaller (Dollery, Fowler, Hugh-Jones, Matthews, and West, 1963). Patients undergoing cerebral angiography would have about 20 skull radiographs taken, with a radiation dose to the skull of approximately 1.5 rads for each radiograph. This is many times more than the radiation received for each injection of $\mathrm{Xe}^{133}$. As the expired gas is led to the outside atmosphere, the radiation hazard to persons in the theatre is negligible.

\section{RESULTS}

Measurements of blood flow through the posterofrontal cortex were made in seven patients undergoing cerebral angiograms. Four of the patients had normal angiograms, one had an aneurysm of the basilar artery, one a small subdural haematoma, and one a right parietal tumour. In five of the patients duplicate determinations were made, before and after passive hyperventilation. The results are shown in Table I. There appears to be a wide scatter of values but these relate extremely well to changes in arterial $\mathrm{pCO}_{2}$. In Table II the flow measurements have been divided into two groups, those measured at arterial $\mathrm{pCO}_{2}$ values greater than $35 \mathrm{~mm}$. $\mathrm{Hg}$ and those less than $30 \mathrm{~mm}$. $\mathrm{Hg}$. (The second result from one patient has been excluded, as no $\mathrm{pCO}_{2}$ value was obtained.) The mean value for flow measurements at a mean $\mathrm{pCO}_{2}$ of 43 was $0.77 \mathrm{ml}$. $/ \mathrm{g}$. $/ \mathrm{min}$. At a mean $\mathrm{pCO}_{2}$ of $25 \mathrm{~mm}$. $\mathrm{Hg}$, the mean flow value is 0.45 $\mathrm{ml} . / \mathrm{g} . / \mathrm{min}$.

\section{TABLE I}

RESULTS OF BLOOD FLOW THROUGH BRAIN CORTEX AND ARTERIAL CARBON DIOXIDE TENSION IN SUBJECTS STUDIED

\begin{tabular}{lccl} 
Patient & $\begin{array}{c}\text { Arterial pCO} \\
(\mathrm{mm} . \mathrm{Hg})\end{array}$ & $\begin{array}{l}\text { Blood Flow } \\
(\text { ml./g./min. })\end{array}$ & Angiogram \\
\hline G.G. & 35 & 0.65 & Aneurysm basilar artery \\
F.B. & 42 & 0.76 & Normal \\
& 20 & 0.44 & Normal \\
W.I. & 27.5 & 0.44 & Subdural haemotoma \\
A.S. & 29.5 & 0.52 & \\
& 19.5 & 0.38 & Right patietal tumour \\
A.B. & 27.5 & 0.53 & (glioblastoma) \\
& -56.28 & 0.92 & Normal \\
B.G. & 56 & 0.38 & Normal \\
F.R. & 30 & 0.75 & \\
& 40 & 0.44 &
\end{tabular}

TABLE II

BLOOD FLOW RESULTS AT CARBON DIOXIDE TENSIONS GREATER THAN 35 MM. HG AND LESS THAN 30 MM. HG

\begin{tabular}{|c|c|c|c|c|}
\hline & \multicolumn{2}{|c|}{$\begin{array}{l}\text { Group } 1 \\
\left({ }_{p} \mathrm{CO}_{2}>35\right)\end{array}$} & \multicolumn{2}{|c|}{$\begin{array}{l}\text { Group } 2 \\
\left(p \mathrm{CO}_{2}<30\right)\end{array}$} \\
\hline & Flow & $\mathrm{pCO}_{2}$ & Flow & $\mathrm{pCO}_{2}$ \\
\hline & $\begin{array}{l}0.65 \\
0.76 \\
0.92 \\
0.75\end{array}$ & $\begin{array}{l}35 \\
42 \\
56 \\
40\end{array}$ & $\begin{array}{l}0.44 \\
0.44 \\
0.52 \\
0.38 \\
0.53 \\
0.38 \\
0.44\end{array}$ & $\begin{array}{l}20 \\
27 \cdot 5 \\
29 \cdot 5 \\
19 \cdot 5 \\
27 \cdot 5 \\
30 \\
20\end{array}$ \\
\hline $\begin{array}{l}\text { Mean } \\
\text { S.D. } \\
\text { Coefficient of variation }(\%)\end{array}$ & $\begin{array}{l}0 \cdot 77 \\
0 \cdot 11 \\
14 \cdot 5\end{array}$ & $\begin{array}{r}43 \\
9 \\
21\end{array}$ & $\begin{array}{l}0.45 \\
0.035 \\
7.8\end{array}$ & $\begin{array}{r}25 \\
5 \\
20\end{array}$ \\
\hline
\end{tabular}

\section{DISCUSSION}

The theory of the inert gas clearance method has been extensively discussed elsewhere (Ingvar and Lassen, 1962). However, one point must be raised. The radioactive gas krypton ${ }^{85}$ used by Lassen and Ingvar has an air:blood partition coefficient of about 20 (Kety, 1951), and is therefore almost completely cleared by the lungs, the effective arterial recirculation to the brain being only a few per cent. However, as xenon ${ }^{133}$ has an air:blood partition coefficient of only 10 , the lung clearance is less efficient and with a two-minute injection period, we have found in preliminary animal experiments that the effect on the initial slope due to recirculation is approximately $5 \%$. Our calculated flow values may, therefore, err slightly on the low side. We would emphasize the importance of using this technique only in patients with normal cardio-pulmonary function. Any lung pathology may interfere with the exchange of xenon in the lungs, with the result of an unacceptably high arterial recirculation.

In these measurements, care was taken to ensure that the injections were made into the internal carotid artery, thus preventing any distortion of the clearance curve by radiation from extracerebral tissues.

The contribution of the white matter to the clearance curve is considered to be small for the following reasons. The collimator is so designed that the maximum efficiency of counting comes from cortical tissue. As white matter has a blood flow very much less than that of grey matter (Landau, Freygang, Roland, Sokoloff, and Kety, 1955), the initial concentration of radioactivity in white matter will be much less than in grey matter and the contribution to the clearance curve correspondingly small.

The blood-flow estimations at a mean arterial $\mathrm{pCO}_{2}$ of $43 \mathrm{~mm}$. $\mathrm{Hg}$ gave a value of $0.77 \mathrm{ml} . / \mathrm{g}$. brain cortex/minute. The only other figure available for blood flow through the cerebral cortex in man is 
$0.51 \mathrm{ml} . / \mathrm{g} . / \mathrm{min}$. (Ingvar and Lassen, 1961). However, this measurement was made on the exposed brain cortex of a patient with a large intracerebral tumour which may have influenced the result. Kety and Schmidt (1948), using the nitrous oxide technique, found values of $0.54 \mathrm{ml} . / \mathrm{g} . / \mathrm{min}$. for total cerebral blood flow in conscious man. As the brain is composed of approximately three-fifths grey matter and twofifths white matter (Rose, 1935), the former having a blood flow approximately three times as great as the latter under light anaesthesia (Kety, 1963), results indicate a total cerebral flow of about $0.56 \mathrm{ml} . / \mathrm{g} . / \mathrm{min}$. if one assumes a fairly uniform blood flow through grey matter under general anaesthesia. There is some evidence that this is true as far as cortical tissue is concerned (Landau et al., 1955; Harper, Glass, and Glover, 1961) but not necessarily so for grey matter in mid-brain structures.

The reduction in cortical blood flow on hyperventilation was $42 \%$. This is slightly greater than the $35 \%$ reduction in total cerebral blood flow reported by Kety and Schmidt (1946) in conscious human volunteers.

There was no significant difference in the bloodflow results between patients with abnormal and normal angiograms. However, these patients were carefully selected beforehand on the grounds that they were fully conscious, rational, and had minimal clinical symptoms. In addition, measurements of blood flow weremadeat some distance from the lesion.

In conclusion, we consider that this adaptation of Lassen and Ingvar's method offers many advantages over other methods for the indirect measurement of cerebral blood flow in man. First, it can be performed very rapidly; there is no tedious analysis of blood samples required by the standard method of Kety and Schmidt (1948). The clearance curves can be analysed and an answer obtained in a few minutes. Secondly, the method gives the average local cortical blood flow over the first $\mathbf{3 0}$ seconds of the clearance curve and not the average intracranial blood flow over 15 minutes, as with Kety's method. Thirdly, local changes in cortical blood flow can be detected which might be missed in measurements of total cerebral blood flow. The main disadvantage is that it necessitates cannulation of the carotid artery, for which reason the procedure will normally be combined with cerebral angiography.

\section{SUMMARY}

Quantitative measurements of local blood flow in the cerebral cortex through the intact skull have been made in anaesthetized patients undergoing carotid angiography. Blood flow was calculated from the rate of clearance from the cortex of xenon ${ }^{133}$ following its injection into the internal carotid artery. The values obtained in normocapnic and hypocapnic patients $\frac{\stackrel{\Phi}{O}}{\text { are reported. }}$

This work was supported by a grant from the Medicalo Research Council. One of us (A.M.H.) is Wellcome seniore research fellow in clinical science. We are very gratefula to Professor W. A. Mackey, Mi. J. Sloan Robertson, and Dr. J. M. A. Lenihan for their continued encouragement and advice. We would like to acknowledge the invaluable $\stackrel{\rho}{-}$ help and cooperation given by the radiological and nurs-⿳⺈⿴囗十 ing staff at Killearn Hospital.

\section{REFERENCES}

Dollery, C. T., Fowler, J. F., Hugh-Jones, P., Matthews, C. M. E., and West, J. B. (1963). The preparation and use of radioactive $\vec{\nabla}$ oxygen, carbon monoxide, and carbon dioxide for investigation of regional lung function, and their comparison with Xenon-133. In Radioaktive Isotope in Klinik und Forschung, Vol. 5. Vorträge am Gasteiner internationaler Symposion 1962,edited by $K$. Fellinger and R. Höfer, pp. 88-103. Urban and. Schwarzenberg, Munich. [Suppl. to Strahlentherapie 53.]

- Hugh-Jones, P., and Matthews, C. M. E. (1962). Use of radio- $\vec{\omega}$ active Xenon for studies of regional lung function. Brit. med.W $J ., 2,1006-1016$.

Glass, H. I. (1963). A depth focusing collimator for the measurement of local cerebral blood flow. To be published.

-, and Harper, A. M. (1963). Measurement of regional bloodiv flow in cerebral cortex of man through intact skull. Brit. med. J., $1,593$.

Harper, A. M., Glass, H. I., and Glover, M. M. (1961). Measurementin of blood flow in the cerebral cortex of dogs, by the clearapese of Krypton ${ }^{85}$. Scot. med. J., 6, 12-17.

Ingvar, D. H., and Lassen, N. A. (1961). Quantitative determination of regional cerebral blood flow in man. Lancet, 2, 806-807. $\sigma \rightarrow$ - (1962). Regional blood flow of the cerebral cortex detur-c mined by Krypton 85. Acta physiol. scand., 54, 325-338. ㄷ

Kety, S. S. (1951). The theory and applications of the exchange inert gas at the lungs and tissues. Pharmacol. Rev., 3, 1-41. (1963). Regional circulation of the brain under physiologizal $\vec{c}$ conditions-possible relationship to selective vulnerability. O In Selective Vulnerability of the Brain in Hypoxaemia, edited by J. P. Schadé and W. H. McMenemey, p. 21. Blackwell, $\square$ Oxford.

- and Schmidt, C. F. (1946). The effects of active and passive hyperventilation on cerebral blood flow, cerebral oxygen con- $\bar{\partial}$ sumption, cardiac output, and blood pressure of normal youngo men. J. clin. Invest., 25, 107-119.

,$- \frac{1}{1948)}$. The nitrous oxide method for the quantitative determination of cerebral blood flow in man: theory, procedure and normal values. J. clin. Invest., 27, 476-483.

Landau, W. M., Freygang, W. H., Roland, L. P., Sokoloff, L., and Kety, S. S. (1955). The local circulation of the living brain; values in the unanesthetized and anesthetized cat. Trans. Amer. neurol. Ass., 80, 125-129.

Lassen, N. A., and Ingvar, D. H. (1961). The blood flow of the cerebral cortex determined by radioactive Krypton 85. Experientia (Basel), 77, 42.

—, Høedt-Rasmussen, K., Sørensen, S. C. Skinhøj, E., Cronquist, S., Bodforss, B., and Ingvar, D. H. (1963). Regional cerebral blood flow in man determined by a radioactive inert gas (Kryp? ton $^{85}$ ). Neurology (Minneap.), 13, 719.

Mallett, B. L., and Veall, N. (1963). Investigation of cerebral blood flow in hypertension using radioactive-Xenon inhalation and extracranial recording. Lancet, $1,1081$.

Matthews, C. M. E., Fowler, J. F., and Turner, P. C. R. (1962). Med. Res. Coun. Cyclotron Unit, Tech. Mem. No. 84.

Rose, M. (1935). Anatomie des Gehirns, Berlin. Quoted by Ingvar, D. H., and Lassen, N. A. (1962). Acta physiol. scand., 54, 三. 325-338.

Siggaard Andersen, O., Engel, K., Jørgensen, K., and Astrup, P. (1960). A micro method for determination of $\mathrm{pH}$, carbon $\mathrm{N}$ dioxide tension, base excess and standard bicarbonate in capillary blood. Scand. J. clin. Lab. Invest., 12, 172-176. 